\title{
COMPARISON OF BODY COMPOSITION AND ENERGY INTAKE OF YOUNG FEMALE BALLET DANCERS AND ORDINARY SCHOOL GIRLS
}

\author{
Lìga Kalniṇa ${ }^{1, \#}$, Guntars Selga ${ }^{2}$, Melita Sauka $^{1}$, Aija Randoha ${ }^{1}$, Eva Krasovska ${ }^{1}$, \\ and Viesturs Lāriṇš ${ }^{3}$ \\ ${ }^{1}$ University of Latvia (Latvia), 19 Raiṇa Blvd., Rìga, LV-1586, LATVIA \\ ${ }^{2}$ Rīga Stradiṇš University (Latvia), 16 Dzirciema Str., Rīga, LV-1007, LATVIA \\ ${ }^{3}$ Latvian Academy of Sports Education, 333 Briviības gatve, Rīga, LV-1006, LATVIA \\ \# Corresponding author, liga.kalnina69@inbox.lv
}

Communicated by Andris Ferdats

\begin{abstract}
The aim of this study is to assess body fat level, energy and nutrient intake of adolescent ballet dancers and to compare these results with those of adolescents from ordinary school. Participants included 39 ballet dancers and 70 adolescents from ordinary school. Body composition was measured using a multi-frequency 8-polar bioelectrical impedance leg-to-hand analyser (X-Scan Plus II, Korea). Dietary intakes were assessed using a three-day estimated food record. Nutritional intake was calculated using the Nutri Survey software. Ballet dancers were slightly shorter, lighter, with less fat and fat-free mass compared to girls from ordinary school. $51.3 \%(95 \% \mathrm{Cl}$ 35.59 to 66.97$)$ of ballet dancers and $4 \%(95 \% \mathrm{Cl}$; 0.27 to 11.15) of ordinary school girls had a body fat level of $12 \%$ or less. The recommended amount of 35-45 kcal energy to $\mathrm{kg}$ fat-free mass for aesthetic sports was not reached by $42.1 \%(95 \% \mathrm{Cl} 27.61$ to $50.65 \%)$ of ballet dancers. No statistically significant difference was found in percent body fat between ballet dancers who consumed energy less than the recommended amount compared to those who ate normally, but fatfree mass $(p<0.05)$ was lower in those who consumed 35-45 $\mathrm{kcal}$ energy to $\mathrm{kg}$ fat-free mass or less compared to those who ate more. The investigated groups had an inadequate intake of minerals and vitamins during the winter period.
\end{abstract}

Key words: ballet dancers, body composition, dietary intake.

\section{INTRODUCTION}

Adolescents have higher nutritional needs due to rapid growth (lean body mass, fat mass, bone mineralisation) and maturational changes associated with the onset of puberty (Croll et al., 2006). Training for beginning ballet dancers starts early at preschool age and quickly becomes highly intense, frequent and long lasting, always with a view to maintain minimal body weight. Because there is a need to maintain low body weight, adolescents often adhere to diets that might result in inadequate energy and nutrient intakes (Sundgot-Borgen and Garthe, 2011; Sundgot-Borgen et al., 2013). Adolescents in leanness-demanding sports have an increased risk of relative energy deficiency in sport syndrome (RED-S) and of developing disordered eating behaviour and eating disorders (EDs) (Melin et al., 2015). RED-S, which is called the 'Female Athlete Triad', refers to impaired physiological function including, but not limited to, metabolic rate, menstrual function, bone health, immu- nity, protein synthesis, and cardiovascular health (Mountjoy et al., 2014).

Body composition is an important health and performance variable. $12 \%$ body fat has recently been suggested as the minimal level for female athlete adolescents, including ballet dancers (Sundgot-Borgen et al., 2013). Adipose tissue is not only a passive store of energy - it is also an active secretory tissue, producing a lot of hormones, cytokines and other metabolically active substances.

Female athletes should consume sufficient energy - 30-45 $\mathrm{kcal} / \mathrm{kg}$ fat-free mass (FFM) daily (Sundgot-Borgen et al., 2013). $30 \mathrm{kcal} \cdot \mathrm{kg}^{-1} \mathrm{FFM} \cdot \mathrm{d}^{-1}$ might be the lower threshold of energy availability for females (Anonymous, 2009). For example, the muscle protein synthesis is reduced even at en-

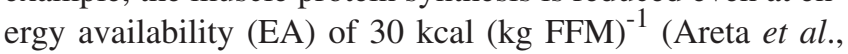
2013). Exposure to as few as five days of low EA has been shown to reduce blood glucose levels and carbohydrate 
availability, suppress the pulsatility of gonadotropinreleasing hormone, reduce hypothalamic-pituitary-axis hormones (such as triiodothyronine and estrogen), and elevate cortisol levels (Loucks and Thuma, 2003). Typical consequences of persistent energy deficiency with or without an ED are reproductive dysfunction, and deficiency/suboptimal status of micronutrients such as iron and calcium (Nattiv et al., 2007; Rauh et al., 2010; Rickenlund et al., 2005).

The aim of this study was to assess body fat level, energy and nutrient intake of adolescent ballet dancers and to compare these results with those of a control group - adolescents from ordinary school.

\section{MATERIALS AND METHODS}

Participants. Taking into account that the physiological demands during ballet training and performances are comparable to those in other aesthetic sports, ballet dancers were, for the purpose of this study, regarded as athletes. Thirtynine female ballet dancers (median age 13 years, range 12-14) and seventy female respondents from ordinary school as controls (median age 14 years, range 13-15) were selected for the study. All ballet dancers were from the Riga Choreography School and had been actively training for at least three years (mean \pm SD; $5.84 \pm 2.39$ years). Training volume at the time of study was $24.42 \pm 3.42 \mathrm{~h} /$ week. Controls reported no history of participation in competitive sports and were not excluded if they participated in recreational sports (mean recreational physical activity duration $3 \pm 2 \mathrm{~h} /$ week). None of the participants reported dieting at the time of the study.

Ethical approval. The study was conducted in accordance with the ethical standards laid down in the 1964 Declaration of Helsinki ( $6^{\text {th }}$ revision 2008). The study was approved by the Rīga Stradiňš University Ethics Committee. Participation was voluntary, based on willingness and written applications by the administrations of the respective sport organisation. After having fully informed the girls and their parents about the study and its aim, informed consent was obtained from both the participants and their parents.

Body composition. Height was measured to the nearest 1 $\mathrm{cm}$ with an ultrasonic height meter (UHM-101, Korea) with children standing with bare feet. Body mass and total body fat were measured using a multi frequency 8-polar bioelectrical impedance leg-to-hand analyser (BIA) (X-Scan Plus II, Korea). The subjects were required to adhere to standard BIA testing guidelines, given in the manufacturer's manual, and the subjects were measured in light clothes. All measurements were performed when the athletes were in a normal rehydrated status.

Food intake. Dietary intakes were assessed using three-day estimated food record, completed by the interviewer by asking about the food eaten in the previous day and using picture series for the estimation of the portion sizes consumed. Dietary intakes were assessed over two non-consecutive weekdays and one weekend day. Nutritional intake was calculated using Nutri Survey software (English version of the German software (EBISpro).

Statistics. Anthropometric and body composition characteristics and daily nutrient intakes were computed as the mean and standard deviation (SD). Daily nutrient intake variables were subjected to analysis of variance (one-way ANOVA) between the control group (ordinary school adolescents) and the study group (ballet dancers), also confidence intervals (CI) were calculated. All calculations were performed using SPSS v.22.0 software for Windows. The significance level was set at $p<0.05$.

\section{RESULTS}

Body composition. Anthropometric characteristics and body composition of the assessed groups are shown in Table 1 . All anthropometric and body composition parameters differed significantly among the investigated groups as well as in the group of 13 years olds ( $p \leq 0.001)$, which consisted of more participants ( 16 ballet dancers and 17 participants from the control group). Ballet dancers were slightly shorter, lighter, with less fat and fat-free mass compared to girls from ordinary school in the same age period. Considering the $12 \%$ level for body fat $(\% \mathrm{BF})$ for aesthetic sports as critical (Sundgot-Borgen et al., 2013), half of ballet dances were too lean for healthy growth and performance. $51.3 \%$ (95\% CI 35.59 to 66.97) of ballet dancers and $4 \%$ (95\% CI 0.27 to 11.15 ) of ordinary school girls had inadequate body fat level. These results differed significantly between the study groups $(p \leq 0.001)$. According to the National Scale, \%BF for the respective age in young athletes (Kalnina et al., 2015) was very low (under the 20 percentile) in $71.79 \%$ (95\% CI 57.76 to 85.91 ) of ballet dancers and $22.86 \%$ (95\% CI 13.02 to 32.70 ) of girls from the control group $\% \mathrm{BF}$. The results differed significantly between the study groups $(p \leq 0.001)$.

Intake of energy and macronutrients. Reported energy and macronutrient intakes are shown in Table 2. The total intake of energy $(p<0.001)$, proteins $(p<0.001)$, carbohydrates $(p<0.001)$ and fat $(p<0.05)$ were lower in ballet dancers compared to the control group. Calculating energy intake to weight $(\mathrm{kg})$, the control group consumed even less

Table 1

ANTHROPOMETRIC AND BODY COMPOSITION CHARACTERISTICS OF YOUNG FEMALE BALLET DANCERS AND FEMALES FROM AN ORDINARY SCHOOL (mean \pm SD)

\begin{tabular}{lcc}
\hline \multicolumn{1}{c|}{ Parameters } & $\begin{array}{c}\text { Ballet dancers } \\
\mathrm{n}=39\end{array}$ & $\begin{array}{c}\text { Controls } \\
\mathrm{n}=70\end{array}$ \\
\hline Height $(\mathrm{cm})$ & $156.23 \pm 8.41$ & $166.74 \pm 6.11$ \\
Weight $(\mathrm{kg})$ & $40.14 \pm 7.69$ & $59.48 \pm 10.94$ \\
Fat mass $(\mathrm{kg})$ & $5.18 \pm 2.52$ & $14.38 \pm 6.39$ \\
$\%$ body fat & $12.43 \pm 3.87$ & $23.13 \pm 6.38$ \\
Fat-free mass $(\mathrm{kg})$ & $34.95 \pm 5.64$ & $45.11 \pm 5.11$
\end{tabular}

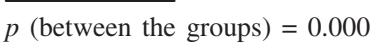


Table 2

DAILY INTAKES OF ENERGY, MACRONUTRIENTS, FIBRE, AND ENERGY-SOURCE DISTRIBUTION OF YOUNG FEMALE BALLET DANCERS AND FEMALES FROM AN ORDINARY SCHOOL (mean \pm $\mathrm{SD})$

\begin{tabular}{|c|c|c|c|}
\hline Measurements & $\begin{array}{c}\text { Controls } \\
\mathrm{n}=70\end{array}$ & $\begin{array}{c}\text { Ballet dancers } \\
\mathrm{n}=39\end{array}$ & $\begin{array}{l}p \text { (between } \\
\text { the groups }\end{array}$ \\
\hline Energy (kcal) & $1700.41 \pm 369.48$ & $1306.21 \pm 288.67$ & 0.00 \\
\hline $\begin{array}{l}\text { Energy (kcal/kg } \\
\text { weight) }\end{array}$ & $29.81 \pm 9.40$ & $33.86 \pm 10.75$ & 0.043 \\
\hline $\begin{array}{l}\text { Energy (kcal/kg fat } \\
\text { free-mass) }\end{array}$ & $38.32 \pm 10.06$ & $38.49 \pm 11.53$ & 0.936 \\
\hline Water $(\mathrm{g})$ & $934.85 \pm 360.32$ & $991.57 \pm 499.05$ & 0.497 \\
\hline Proteins (g) & $87.62 \pm 31.39$ & $47.10 \pm 16.18$ & 0.000 \\
\hline $\begin{array}{l}\text { Proteins }(\mathrm{g} / \mathrm{kg} \\
\text { weight) }\end{array}$ & $1.55 \pm 0.78$ & $1.22 \pm 0.50$ & 0.190 \\
\hline $\begin{array}{l}\text { Proteins }(\mathrm{g} / \mathrm{kg} \text { fat } \\
\text { free mass) }\end{array}$ & $1.99 \pm 0.89$ & $1.39 \pm 0.55$ & 0.000 \\
\hline Fat $(\mathrm{g})$ & $51.96 \pm 9.53$ & $45.69 \pm 13.26$ & 0.005 \\
\hline Fat (g/kg weight) & $0.90 \pm 0.23$ & $1.17 \pm 0.43$ & 0.000 \\
\hline $\begin{array}{l}\text { Fat }(\mathrm{g} / \mathrm{kg} \text { fat-free } \\
\text { mass) }\end{array}$ & $1.16 \pm 0.24$ & $1.34 \pm 0.46$ & 0.011 \\
\hline Carbohydrates (g) & $219.61 \pm 46.68$ & $174.56 \pm 56.34$ & 0.000 \\
\hline $\begin{array}{l}\text { Carbohydrates ( } \mathrm{g} / \mathrm{kg} \\
\text { weight) }\end{array}$ & $3.84 \pm 1.35$ & $4.53 \pm 1.83$ & 0.027 \\
\hline $\begin{array}{l}\text { Carbohydrates ( } \mathrm{g} / \mathrm{kg} \\
\text { fat-free mass) }\end{array}$ & $4.94 \pm 1.18$ & $5.15 \pm 2.01$ & 0.539 \\
\hline Fibre (g) & $14.57 \pm 3.54$ & $13.03 \pm 5.2$ & 0.071 \\
\hline Fibre (g/kg weight) & $0.25 \pm 0.007$ & $0.34 \pm 0.16$ & 0.000 \\
\hline ( $\mathrm{g} / \mathrm{kg}$ fat free mass) & $0.33 \pm 0.08$ & $0.38 \pm 0.18$ & 0.025 \\
\hline \multicolumn{4}{|l|}{$\%$ kilocalories from } \\
\hline protein & $20.66 \pm 5.08$ & $14.47 \pm 3.53$ & 0.000 \\
\hline carbohydrates & $51.10 \pm 5.81$ & $53.08 \pm 98.87$ & 0.162 \\
\hline fat & $28.02 \pm 4.36$ & $31.76 \pm 7.38$ & 0.001 \\
\hline
\end{tabular}

than ballet dancers $(p<0.05)$ but the energy to fat-free mass was similar. The recommended amount of 35-45 kcal energy to kg fat-free mass for aesthetic sports was not reached in $42.1 \%$ (95\% CI 27.61 to 50.65 ) of ballet dancers. Regarding energy intake to kg FFM in adolescents from ordinary school, $39.1 \%$ (95\% CI 26.4 to 57.83 ) consumed energy less than $35-45 \mathrm{kcal}$, which did not differ significantly in the ballet dancer group $(p>0.05)$ who underwent intensive physical activity. Ballet dancers consumed more fat $(p<0.001)$ and carbohydrates $(p<0.05)$ to weight $(\mathrm{kg})$, than the control group but both consumed the same amount of proteins $(p>0.05)$. Regarding FFM $(\mathrm{kg})$, which in our opinion could be more accurate, both groups consumed the same amount of carbohydrates $(p>0.05)$, and ballet dancers consumed slightly more fat $(p<0.05)$ and less proteins $(p<0.001)$ compared to the control group.

The mean intake of energy and all macronutrients of ballet dancers who consumed less than $35 \mathrm{kcal} / \mathrm{kg}$ FFM was significantly lower than those consuming 35-45 or more $\mathrm{kcal} / \mathrm{kg}$ FFM $(p<0.001)$. The mean weight and body mass index (BMI) were less for those who consumed less than 35 $\mathrm{kcal} / \mathrm{kg}$ FFM $(p<0.05)$. No statistically significant difference was found in \%BF or FM (mean \%BF $13.7 \pm 3.7$ vs.
$11.4 \pm 3.7 ; p>0.05$ ) or fat mass index (FMI), while FFM $(p<0.05)$ and fat free mass index (FFMI) $(p<0.001)$ were lower in the group consuming 35-45 or less kcal $/ \mathrm{kg}$ fat-free mass.

Intake of minerals and vitamins. The mean of daily intake of minerals and vitamins are shown in Tables 3 and 4. The total daily intake of minerals and vitamins in ballet dancers was less than in the control group.

Analysing the mean intake of minerals, both groups consumed less than amounts recommended for their age and gender. Ballet dancers consumed less minerals compared to the girls from ordinary school, especially potassium, calcium, phosphorus and iron $(p<0.001)$.

Comparing ballet dancers who consume less than $35 \mathrm{kcal}$ $/ \mathrm{kg}$ FFM (group I) and those consuming more than 35-45 $\mathrm{kcal} / \mathrm{kg}$ FFM (group II), the daily intake of all minerals except Na was less for group I, and the difference was statistically significant $(p<0.05)$ especially for $\mathrm{P}$ and $\mathrm{Zn}(p<$ $0.001)$. The daily intake of minerals did not differ statistically significantly between groups who had less or more than $12 \%$ of body fat $(p>0.05)$.

Analysing the mean intake of vitamins, ballet dancers consumed less vitamin $\mathrm{E}$ and vitamin $\mathrm{B}_{2}$ and $\mathrm{B}_{6}$ compared to the control group $(p<0.001)$. During the winter period, both investigated groups may be at risk of deficiency of specific vitamins, especially vitamins $\mathrm{A}, \mathrm{E}$, and $\mathrm{B}$.

\section{DISCUSSION}

We investigated adolescents from the Rìga Choreography School and one ordinary school in Rìga to assess nutritional status (\% BF and FFM) and food intake during the winter period.

Given the biological changes occurring in female athletes during adolescence, it is important to remember that the body of a young growing athlete often develops in a direction against the paradigm of the athlete's sport, especially in women and where the sport demands being as lean as possible (Sundgot-Borgen et al., 2013). The current study showed that young ballet dancers had significantly lower anthropometric and body composition than that of the control group. Half of the ballet dancers had \%BF under the recommended level $(12 \%)$ and for $41 \%$ the daily intake of energy (35-45 g/kg FFM) was inadequate. It seems that pressure for leanness to our ballet dancers was quite high and against the direction of normal biological changes. The mean $\% \mathrm{BF}$ (mean $\pm \mathrm{SD}$ ) was slightly lower for ballet dancers than in a study conducted in Croatia $(12.4 \% \pm 3.8$ vs. $17.4 \% \pm 4.7 \%$ ) for the same age group (Soric et al., 2008).

We found that ballet dancers who ate less than recommended in order to maintain the minimum weight and dieting, did not have a reduced level of fat but had a reduced level of fat free mass or mainly muscle mass. Therefore, 
DAILY MINERAL INTAKES (mean \pm SD)

\begin{tabular}{|c|c|c|c|c|c|c|}
\hline \multirow[b]{2}{*}{ Mineral } & \multirow[b]{2}{*}{ Recommended* ${ }^{*}$} & \multicolumn{2}{|c|}{$\begin{array}{c}\text { Ballet dancers } \\
\mathrm{n}=39 \\
\end{array}$} & \multicolumn{2}{|c|}{$\begin{array}{c}\text { Controls } \\
\mathrm{n}=70\end{array}$} & \multirow[b]{2}{*}{$\begin{array}{c}p \text { (mean between } \\
\text { the groups) }\end{array}$} \\
\hline & & mean $\pm \mathrm{SD}$ & $\begin{array}{c}\%(\mathrm{CI}) \text { of group } \\
\text { below recommended }\end{array}$ & mean $\pm \mathrm{SD}$ & $\begin{array}{c}\%(\mathrm{CI}) \text { of group } \\
\text { below recommended }\end{array}$ & \\
\hline Sodium (mg) & $\begin{array}{l}1800 \text { (age } 11-14) \\
2200(\text { age } 15-18)\end{array}$ & $1725.35 \pm 766.36$ & $\begin{array}{c}35.90 \\
(20.84-50.96)\end{array}$ & $1932.93 \pm 771.42$ & $\begin{array}{c}24.29 \\
(14.24-34.34)\end{array}$ & 0.180 \\
\hline Potassium (mg) & $\begin{array}{c}3000 \text { (age } 11-14) \\
3700 \text { (age 15-18) }\end{array}$ & $1729.31 \pm 456.67$ & 100 & $2204.35 \pm 561.29$ & 100 & 0.000 \\
\hline Calcium (mg) & 1200 & $512.47 \pm 250.92$ & $\begin{array}{c}97.44 \\
(92.48-102.40)\end{array}$ & $584.64 \pm 292.78$ & $\begin{array}{c}98.57 \\
(95.79-101.35)\end{array}$ & 0.198 \\
\hline Magnesium (mg) & 350 & $207.50 \pm 86.87$ & $\begin{array}{c}94.87 \\
(87.95-101.79)\end{array}$ & $235.15 \pm 58.31$ & $\begin{array}{c}95.71 \\
(90.74-100.39)\end{array}$ & 0.050 \\
\hline Phosphorus (mg) & 1200 & $775.43 \pm 217.01$ & 100 & $1028.94 \pm 279.02$ & $\begin{array}{c}78.57 \\
(68.96-88.18)\end{array}$ & 0 \\
\hline Iron (mg) & $\begin{array}{l}12 \text { (age } 11-14) \\
15 \text { (age } 15-18)\end{array}$ & $8.14 \pm 2.53$ & $\begin{array}{c}64.10 \\
(87.95-101.70)\end{array}$ & $9.90 \pm 2.19$ & $\begin{array}{c}97.14 \\
(93.24-101.40)\end{array}$ & 0 \\
\hline Zinc (mg) & $\begin{array}{l}12 \text { (age } 11-14) \\
14 \text { (age 15-18) }\end{array}$ & $5.81 \pm 1.99$ & $\begin{array}{c}84.62 \\
(73.30-93.94)\end{array}$ & $9.77 \pm 3.23$ & $\begin{array}{c}38.57 \\
(27.17-49.97)\end{array}$ & 0 \\
\hline
\end{tabular}

* Recommended energy and nutrient intake for Latvian population (approved by Ministry of Health of the Republic of Latvia in 2008)

Ta ble 4

DAILY VITAMIN INTAKE

\begin{tabular}{|c|c|c|c|c|c|c|}
\hline \multirow[t]{2}{*}{ Vitamin } & \multirow[t]{2}{*}{ Recommended* } & $\begin{array}{l}\text { Ballet dancers } \\
\quad \mathrm{n}=39\end{array}$ & $\begin{array}{c}\%(\mathrm{CI}) \text { of group } \\
\text { below recommended }\end{array}$ & $\begin{array}{c}\text { Controls } \\
\mathrm{n}=70\end{array}$ & $\begin{array}{c}\%(\mathrm{CI}) \text { of group } \\
\text { below recommended }\end{array}$ & \multirow[t]{2}{*}{$\begin{array}{c}p \text { (mean between } \\
\text { the groups) }\end{array}$} \\
\hline & & mean $\pm \mathrm{SD}$ & $\%(95 \% \mathrm{Cl})$ & mean $\pm \mathrm{SD}$ & $\%(95 \% \mathrm{Cl})$ & \\
\hline Vitamin A $(\mu \mathrm{g})$ & 1000 & $634.19 \pm 407.09$ & $\begin{array}{c}89.74 \\
(80.22-99.26)\end{array}$ & $744.84 \pm 362.41$ & $\begin{array}{c}75.71 \\
(65.66-85.76)\end{array}$ & 0.149 \\
\hline ß-Carotene $(\mu \mathrm{g})$ & & $2.60 \pm 2.17$ & & $2.02 \pm 1.64$ & & 0.123 \\
\hline Vitamin E (mg) & $\begin{array}{l}10 \text { (age } 11-14) \\
12 \text { (age } 15-18)\end{array}$ & $3.38 \pm 2.07$ & 100 & $9.24 \pm 4.71$ & $\begin{array}{c}77.14 \\
(67.3-86.98)\end{array}$ & 0.000 \\
\hline Vitamin B1 (mg) & 1.2 & $1.03 \pm 0.65$ & $\begin{array}{c}28.20 \\
(14.08-42.32)\end{array}$ & $1.12 \pm 0.41$ & $\begin{array}{c}45.71 \\
(11.67-57.38)\end{array}$ & 0.399 \\
\hline Vitamin B2 (mg) & $\begin{array}{l}1.5 \text { (age } 11-14 \text { ) } \\
1.6 \text { (age } 15-18 \text { ) }\end{array}$ & $0.93 \pm 0.34$ & $\begin{array}{c}89.74 \\
(80.22-99.26)\end{array}$ & $1.18 \pm 0.37$ & $\begin{array}{c}80.00 \\
(70.63-89.37)\end{array}$ & 0.001 \\
\hline Vitamin B6 (mg) & $\begin{array}{l}1.7 \text { (age } 11-14) \\
2.0(\text { age } 15-18)\end{array}$ & $0.92 \pm 0.49$ & $\begin{array}{c}97.43 \\
(92.46-102.4)\end{array}$ & $1.45 \pm 0.42$ & $\begin{array}{c}77.14 \\
(67.3-86.98)\end{array}$ & 0.000 \\
\hline Folic acid $(\mu \mathrm{g})$ & $\begin{array}{l}150 \text { (age } 11-14) \\
200(\text { age } 15-18)\end{array}$ & $207.10 \pm 113.13$ & $\begin{array}{c}25.64 \\
(11.94-39.34)\end{array}$ & $172.97 \pm 74.21$ & $\begin{array}{c}52.85 \\
(41.16-64.54)\end{array}$ & 0.060 \\
\hline Vitamin C (mg) & $\begin{array}{r}75 \text { (age } 11-14) \\
100 \text { (age 15-18) }\end{array}$ & $86.84 \pm 40.95$ & $\begin{array}{c}38.46 \\
(23.19-53.73)\end{array}$ & $79.68 \pm 44.06$ & $\begin{array}{c}61.42 \\
(50.02-72.82)\end{array}$ & 0.407 \\
\hline
\end{tabular}

$\bar{*}$ Recommended energy and nutrient intake for Latvian population (approved by Ministry of Health of the Republic of Latvia in 2008)

these young adolescent ballet dancers were under the risk of development of RED-s (or Athlete triad). In order to maintain leanness and dieting, these $40 \%$ of ballet dancers reduced muscle mass without reducing fat mass (and without improving body shape). It means they were not only at health risk, but also at risk of decreased performance and with great possibility in future to be asked to leave this profession at all. Findings from this study corresponds to the literature (Bernadot, 2012), where this kind of dieting (fasting) is mentioned as one of the greatest health risk at adolescent age.

Findings from the ordinary school showed that $4 \%$ of girls had a fat level less than $12 \%$. Calculating their energy in- take to FFM, 39\% of girls had energy intake less then recommended for aesthetic sports (but they did no undergo any intensive physical activity). It seems that because of massive advertisements for being lean and talking only of the risk of too much fat, normal ordinary school girls, and not only ballet dancers, practise diets to reduce weight. According to our knowledge, there is no research on food intake in the ordinary school population calculated to FFM.

More research is needed to assess the nutritional status of adolescent ballet dancers. Research (Żuława and Pilch, 2012) has documented deficiencies in fats, fibre, minerals like $\mathrm{K}, \mathrm{Ca}, \mathrm{Fe}, \mathrm{Mg}$, and vitamins $\mathrm{B}_{1}$ and $\mathrm{PP}$. The mean consumed energy (kcal) in that study was higher than in the 
current study (1965.48 \pm 156.32 vs. $1306.21 \pm 288.67)$. Comparing our results to those of a study from New Zeeland (Beck et al., 2015) our ballet dancers consumed less energy $(1306.21 \pm 288.67$ via $1925.23 \pm 515.23 \mathrm{kcal})$. However, the comparisons are not completely valid due to age differences (14-18 years compared to our age group 12-14 years old). Nevertheless, both studies showed inadequate intake of nutrients (minerals and vitamins).

\section{CONCLUSION}

In half of the studied adolescent ballet dancers, body fat was under the recommended 12\%. Assessing energy intake, $41 \%$ of ballet dancers did not consume an adequate amount of energy (35-40 g/kg FFM). There is no significant difference the proportion of dieting ballet dancers (42\%) and ordinary school girls $(39 \%)$ in consumed energy to FFM less than 35-45 kcal. Both investigated groups had an inadequate intake of minerals and vitamins during the winter period. There is a need to evaluate immediately our young ballet dancers for other signs of Female Athlete Triad to avoid serious health damage.

\section{REFERENCES}

Anonymous (2009). American College of Sports Medicine position stand. Nutrition and athletic performance. American Dietetic Association, Dietitians of Canada, American College of Sports Medicine, Rodriguez, N., R., Di Marco, N., M., Langley, S. Med. Sci. Sports Exerc., 41 (3), 709-731.

Areta, J. L., Burke, L., M., Ross, M. L., Camera, D. M., West, D. W., Broad, E. M., Jeacocke, N. A., Moore, D. R., Stellingwerff, T., Phillips, S. M., Hawley, J. A., Coffey, V. G. (2013). Timing and distribution of protein ingestion during prolonged recovery from resistance exercise alters myofibrillar protein synthesis. J. Physiol., 591 (9), 2319-2331.

Beck, K. L., Mitchell, S., Foskett, A, Conlon, C. A., von Hurst, P. R. (2015). Dietary intake, anthropometric characteristics, and iron and vitamin D status of female adolescent ballet dancers living in New Zealand. Int. J. Sport Nutr. Exerc. Metab., 25 (4), 335-343.

Benardot, D. (2012). Advanced Sports Nutrition. 2nd ed. Human Kinetics, Champaign, IL. 424 pp. (at p. 341).

Croll, J., K., Neumark-Sztainer D., Story, M., Wall, M., Perry, C., Harnack, L. (2006). Adolescents involved in weight-related and power team sports

Received 13 October 2016

Accepted in the final form 18 November 2017 have better eating patterns and nutrient intakes than non-sport-involved adolescents. J. Amer. Diet Assoc., 106 (5), 709-717.

Kalnina, L., Sauka, M., Timpka, T., Dahlström, Ö., Nylander, E., Selga, G., Ligere, R., Karklina, H., Priedite, I., S., Larins, V. (2015). Body fat in children and adolescents participating in organized sports: Descriptive epidemiological study of 6048 Latvian athletes. Scand. J. Publ. Health, 43 (6), 615-622.

Loucks, A., B., Thuma J., R. (2003). Luteinizing hormone pulsatility is disrupted at a threshold of energy availability in regularly menstruating women. J. Clin. Endocrinol. Metab., 88 (1), 297-311.

Melin, A., Tornberg, Å. B., Skouby, S., Møller, S. S., Sundgot-Borgen, J., Faber, J., Sidelmann, J. J., Aziz, M., Sjödin, A. (2015). Energy availability and the female athlete triad in elite endurance athletes. Scand. J. Med. Sci. Sports, 25 (5), 610-622.

Mountjoy, M., Sundgot-Borgen, J., Burke, L., Carter, S., Constantini, N., Lebrun, C., Meyer, N., Sherman, R., Steffen, K., Budgett, R., Ljungqvist, A. (2014). The IOC consensus statement: beyond the Female Athlete Triad-(RED-S). Brit. J. Sports Med., 48 (7), 491-497.

Nattiv, A., Loucks, A., B, Manore, M., M., Sanborn, C., F., Sundgot-Borgen, J., Warren, M., P., American College of Sports Medicine. (2007). The female athlete triad special communications: position stand. Med. Sci. Sports Exerc., 39 (10), 1867-1882.

Rauh, M., J., Nichols, J., F., Barrack, M., T. (2010). Relationships among injury and disordered eating, menstrual dysfunction, and low bone mineral density in high school athletes: A prospective study. J. Athl. Train, 45 (3), $243-252$.

Recommended energy and nutrient intake for Latvian population (approved by Ministry of Health of the Republic of Latvia in 2008) http://www.vm.gov.lv/images/userfiles/ieud.pdf

Rickenlund, A., Eriksson, M. J., Schenck-Gustafsson, K., Hirschberg, A. L. (2005). Amenorrhea in female athletes is associated with endothelial dysfunction and unfavorable lipid profile. J. Clin. Endocrinol. Metab., 90 (3), 1354-1359.

Soric, M., Misigoj-Durakovic, M., Pedisic, Z. (2008). Dietary intake and body composition of prepubescent female aesthetic athletes. Int. J. Sport Nutr. Exerc. Metab., 18 (3), 343-354.

Sundgot-Borgen, J., Meyer, N. L., Lohman, T. G., Ackland, T. R., Maughan, R. J., Stewart, A. D., Müller, W. (2013). How to minimise the health risks to athletes who compete in weight-sensitive sports review and position statement on behalf of the Ad Hoc Research Working Group on Body Composition, Health and Performance, under the auspices of the IOC Medical Commission. Brit. J. Sports Med., 47 (16), 1012-1022.

Sundgot-Borgen, J., Garthe, I. (2011). Elite athletes in aesthetic and Olympic weight-class sports and the challenge of body weight and body compositions. J. Sports Sci., 29 (Suppl. 1), S101-S114.

Żuława, G., Pilch, W. (2012). The estimation of nutrition habit of ballet school students in Krakow. Rocz Panstw. Zakl. Hig., 63 (1), 105-110.

\section{ĶERMEN̦A UZBŪVES UN UZṆEMTĀS ENERĢIJAS SALĪDZINĀJUMS JAUNĀM BALETA DEJOTĀJĀM UN PARASTĀM SKOLNIECĒM}

Pētījuma mērḳis ir novērtēt jauno baleta dejotāju ķermeņa tauku \% daudzumu, uzņemto enerğijas un uzturvielu daudzumu un salīdzināt iegūtos rezultātus ar pusaudzēm, kuras mācās parastā skolā. Pētījumā ietvertas 39 pusaudzes baleta dejotājas un 70 pusaudzes no parastas skolas kā kontroles grupa. Ķermeņa tauku \% daudzums noteikts, izmantojot daudzfrekvenču bioelektriskās impedances analizatoru (X-Scan Plus II, Koreja). Uzturvielu novērtēšanai izmantota trīs dienu uztura dienasgrāmata. Uzṇemtās uztura vielas aprēkinātas, izmantojot Nutri Survey programmu. Baleta dejotājas ir nedaudz īsākas, vieglākas, ar mazāku tauku un beztauku masu, salīdzinot ar meitenēm parastā skolā. Tauku procentuālais daudzums $12 \%$ un mazāk konstatēts 51,3\% (95\% CI 35,59-66,97) baleta dejotāju un 4\% (95\% CI, 0,27-11,15) meitenēm parastā skolā. Ieteicamo enerğijas daudzumu estētiskam sporta veidam $35-45 \mathrm{kcal} / \mathrm{kg}$ beztauku masas neuzṇem $42,1 \%$ (95\% CI 27,61-50,65\%) baleta dejotājas un $39 \%(95 \%$ CI 26,4-57,6) meitenes, kas mācās parastā skolā. Nav statistiski nozīmīgu atškirīibu tauku procentuālā daudzumā starp baleta dejotājām, kuras uzṇem nepietiekamu enerǵijas daudzumu, un tām, kuras uzṇem enerğiju atbilstoši rekomendācijām, bet beztauku masa $(p<0,05)$ ir zemāka baleta dejotājām, kuras èd nepietiekami, salīdzinot ar baleta dejotājām, kuras ēd normāli. Abu pētījuma grupu dalībniecēm ziemas periodā konstatēts nepietiekams uzṇemto minerālvielu un vitamīnu daudzums. 